\title{
Current Update on the Diagnosis, Management and Pathogenesis of Elastofibroma Dorsi
}

\author{
JUN NISHIO $^{1}$, SHIZUHIDE NAKAYAMA ${ }^{1}$, KAZUKI NABESHIMA $^{2}$ and TAKUAKI YAMAMOTO ${ }^{1}$ \\ ${ }^{1}$ Department of Orthopaedic Surgery, Faculty of Medicine, Fukuoka University, Fukuoka, Japan; \\ ${ }^{2}$ Department of Pathology, Faculty of Medicine, Fukuoka University, Fukuoka, Japan
}

\begin{abstract}
Elastofibroma dorsi is an uncommon benign fibroblastic pseudotumor that typically occurs in the subscapular region of middle-aged or older individuals. The pathogenesis is still unclear and a matter of debate. Magnetic resonance imaging can be used as a first-line investigation of the lesion and reveals a lenticular soft-tissue mass with a signal intensity similar to that of skeletal muscle interlaced with strands of fat. Biopsy is not necessary if all pathognomonic criteria are present. A conservative "wait and see" attitude is reasonable and immediate surgery is no more the standard treatment of elastofibroma dorsi. This review provides an updated overview of the diagnosis, management and pathogenesis of elastofibroma dorsi. We also discuss recent advances in our understanding of genomic alterations in elastofibroma dorsi.
\end{abstract}

Elastofibroma dorsi is a rare benign soft-tissue pseudotumor first described by Jarvi and Saxen in 1961 (1). It belongs to the fibroblastic/myofibroblastic tumor group according to the 2020 World Health Organization Classification of Tumours of Soft Tissue and Bone (2). The lesion usually arises beneath the rhomboid major and latissimus dorsi muscles adjacent to the inferior angle of the scapula. Current knowledge on the genetic features of this peculiar condition is mostly limited. In this review, we present an updated overview of the diagnosis, management and pathogenesis of elastofibroma dorsi. We also discuss recent advances in our understanding of genomic alterations in elastofibroma dorsi.

This article is freely accessible online.

Correspondence to: Jun Nishio, MD, Ph.D., Department of Orthopaedic Surgery, Faculty of Medicine, Fukuoka University, $7-$ 45-1 Nanakuma, Jonan-ku, Fukuoka 814-0180, Japan. Tel: +81 928011011, Fax: +81 928649055, e-mail: jnishio@ cis.fukuoka-u.ac.jp

Key Words: Elastofibroma, magnetic resonance imaging, diagnosis, management, pathogenesis, review.

\section{Clinical Features}

Elastofibroma dorsi may be an incidental radiologic finding. It has a peak incidence in the seventh to eighth decades of life, with a female predominance. Children are rarely affected. Elastofibroma dorsi typically presents as a firm, slow-growing, painless mass and can occur bilaterally. The process has a strong tendency to develop between the inferomedial portion of the scapula and the chest wall at the level of sixth to eighth ribs (Figure 1). When symptoms are present, they are usually mild pain, discomfort or clunking of the scapula during movement of the shoulder. The diameter ranges from 2 to 15 $\mathrm{cm}$ (2). In our experience, spontaneous regression is extremely rare. There is no metastatic potential and no reports of malignant transformation.

\section{Radiologic Findings}

Various imaging modalities have been applied for the detection and follow-up of elastofibroma dorsi. In our experience, magnetic resonance imaging (MRI) is the mainstay of imaging in elastofibroma dorsi. It is essential to be familiar with the key imaging findings of elastofibroma dorsi for its accurate diagnosis and appropriate management. Plain radiographs are usually normal but may occasionally show a soft-tissue mass without calcification. Although reported, bone erosion is extremely unusual. Four ultrasound patterns have been detected (3). A heterogenous fasciculated pattern is most frequently seen. Color Doppler evaluation has not shown significant blood flow (3). Computed tomography (CT) usually shows a poorly defined, crescent shaped, heterogeneous soft-tissue mass with attenuation similar to that of skeletal muscle and linear streaks of fat attenuation (Figure 2). In our experience, CT is less sensitive than MRI for visualizing the streaks of adipose tissue. MRI clearly demonstrates a lenticular, poorly circumscribed, heterogeneous soft-tissue mass (4-6). On both T1- and T2-weighted images (Figure 3), the lesion 


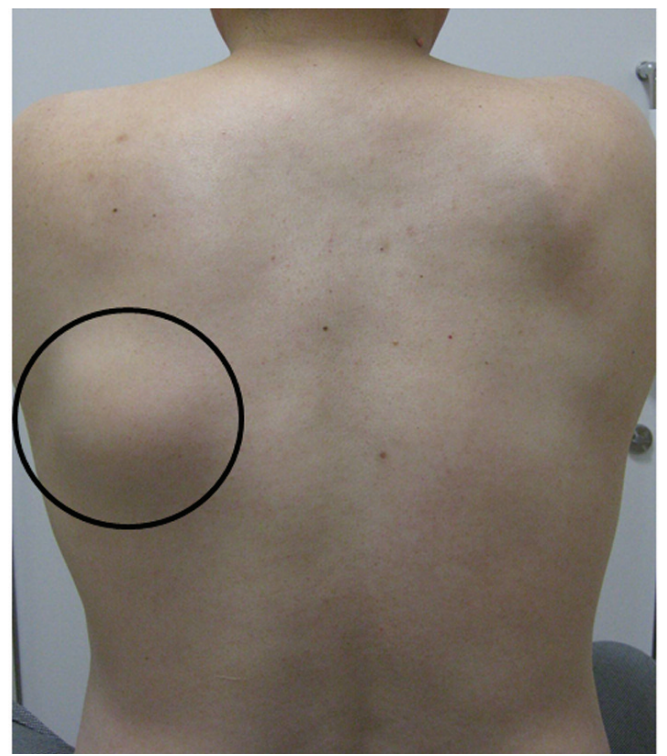

Figure 1. Clinical photograph reveals a palpable mass (circle).

displays intermediate signal intensity similar to that of skeletal muscle with interspersed linear and curvilinear areas of high signal intensity. The absence of abnormal diffusion restriction has been reported (6). Gadoliniumenhanced MRI reveals heterogeneity containing areas with and without contrast enhancement. In our opinion, contrast administration is not necessary to characterize the lesion. Integrated positron-emission tomography (PET)/CT images show mild to moderate fluorodeoxyglucose (FDG) uptake by the lesion $(7,8)$. It is known that elastofibroma dorsi is often incidentally detected as an FDG-avid mass on PET/CT (9).

\section{Histological and Immunohistochemical Characteristics}

Elastofibroma dorsi presents a typical macroscopical and histological aspect. Macroscopically, it appears as an illdefined, rubbery to firm mass. Cut surface displays strands of gray-white fibrous tissue with variable amounts of entrapped yellow adipose tissue (Figure 4). Histologically, the lesion is composed of a mixture of paucicellular fibrocollagenous tissue, a large number of abnormal elastic fibres, scattered spindle cells and entrapped mature fat cells (Figure 5A). Cystic change within the lesion may be seen. Mitotic figures and nuclear pleomorphism are not found. Elastica van Gieson stain reveals numerous globules and branched or unbranched fibres (Figure 5B). Immunohistochemically, the spindle cells are positive for vimentin, CD34 and lysozyme (10). Expression of smooth muscle actin, desmin and S-100 protein is absent.

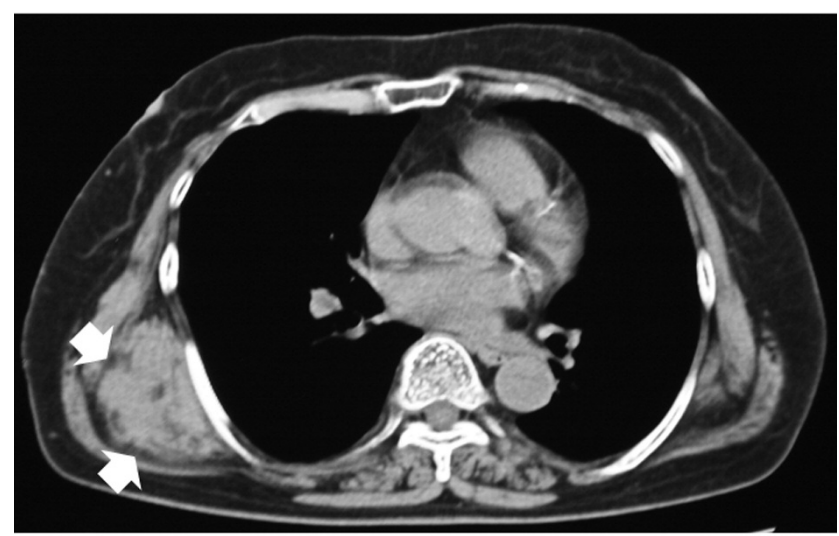

Figure 2. Axial computed tomography shows a poorly circumscribed, lenticular mass (arrows) with attenuation similar to that of skeletal muscle and linear streaks of fat attenuation.

\section{Cytogenetic and Molecular Genetic Findings}

Cytogenetic analyses of elastofibroma dorsi have shown significant chromosomal instability, with clonal and nonclonal structural changes (11-13). Aberrations of the short arm of chromosome 1 are particularly notable. Previously, we identified the presence of DNA copy number changes in 9 of $27(33 \%)$ cases of elastofibroma dorsi (14). The most common recurrent change was a gain of Xq12-q22. In 2006, a nonrandom inactivation of $\mathrm{X}$-chromosome-linked androgen receptor gene was detected in 2 cases of elastofibroma dorsi (10). In 2010, Hernández et al. (15) described losses of 1p36-p31, 19p13.3-q13.1 and 22q11-q13 and a gain of 6p25q25. In that study, deletions of calcium sensing receptor $(C A S R)$, Glutathione S-transferase Pi 1 (GSTP1) and BRCA2 DNA repair associated $(B R C A 2)$ and gains of $A P C$ regulator of WNT signaling pathway $(A P C)$ and phenylalanine hydroxylase $(P A H)$ were also identified. These findings suggest that elastofibroma dorsi is a possible neoplastic process. However, further studies are needed to better understand the correlation between certain genomic alterations and distinct biological behavior.

\section{Diagnosis and Management}

In our experience, the lesion can be confidently diagnosed by radiologic examination alone (ideally MRI) if typical clinical features are present. Although we performed biopsy to obtain a diagnosis of elastofibroma dorsi in the past, this is no longer our standard practice. We propose that biopsy is necessary only when the lesion has enlarged rapidly within 


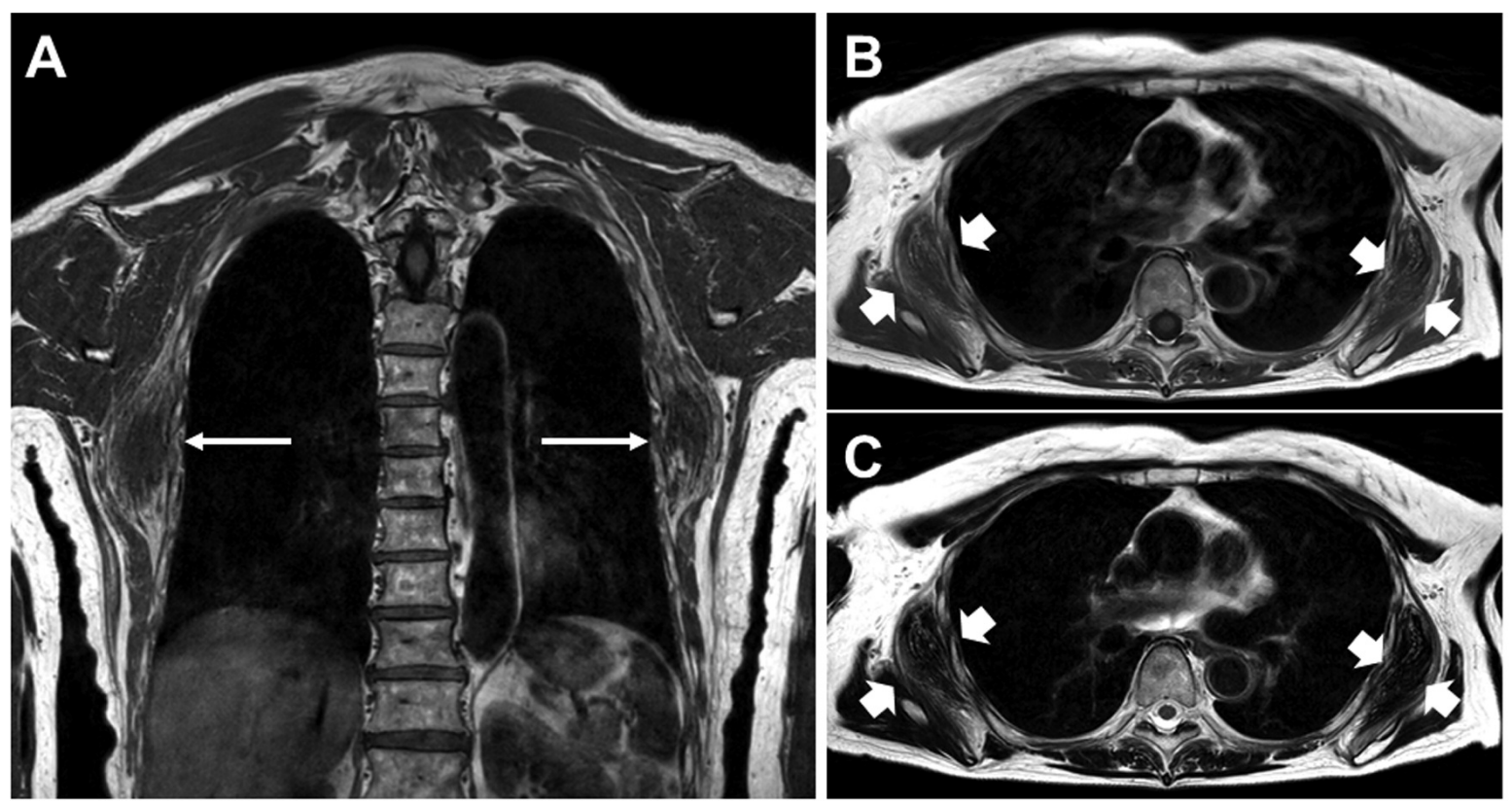

Figure 3. Magnetic resonance images of elastofibroma dorsi. (A) Coronal T1-weighted image reveals bilateral lesions (arrows) in the subscapular region. Corresponding axial T1-weighted $(B)$ and T2-weighted $(C)$ images show bilateral heterogeneous soft-tissue masses (arrows) with a signal intensity approximately equal to that of skeletal muscle, interlaced with areas of signal intensity similar to that of fat.

a few months or imaging findings are atypical. Once the diagnosis is established, follow-up radiologic examinations will be unnecessary.

The differential diagnosis for elastofibroma dorsi is limited and includes fibrolipoma and desmoid-type fibromatosis. Fibrolipoma is a rare variant of lipoma and has a prominent fibrous tissue component in addition to mature adipose tissue element (16). If fibrolipoma has a marked hypointense signal on all pulse sequences, it may have imaging findings that overlap with those of elastofibroma dorsi. Desmoid-type fibromatosis is a locally aggressive fibroblastic neoplasm that can occur in the subscapular location (17). In our experience, the presence of linear fascial extensions and low signalintensity bands on MRI is characteristic of desmoid-type fibromatosis. Histologically, unlike elastofibroma dorsi, these neoplasms lack the abnormal elastic element.

The management of elastofibroma dorsi is somewhat controversial. In our experience, simple observation is a treatment option that can always be considered. It is reasonable to wait at least a year or two in order to understand whether the disease is stable or progressing. On the other hand, Nagano et al. (18) proposed that surgery should only be recommended for symptomatic patients. Chandrasekar et al. (19) suggested that patient preference is also important. If symptomatic patients choose to have surgery, a marginal excision is sufficient and can be performed with minimal morbidity. However, a high incidence of postoperative complications such as seroma or hematoma has been reported in the literature $(18,20)$. We recommend the use of postoperative wound drainage and compression bandage to prevent these complications (4).

\section{Pathogenesis}

There are various opinions regarding the pathogenesis of elastofibroma dorsi. Familial occurrence has been reported in Japan and Europe (21-24). In the largest series of the lesion, 55 of 170 (32\%) cases occurred within the same family lines (21). These findings suggested a genetic predisposition of this lesion. However, many authors believe that elastofibroma dorsi is caused by friction of the lower scapula against the thoracic wall due to repetitive minor trauma and manual labor (25-27). In addition, some other factors may underlie its pathogenesis, including vascular insufficiency, elastotic degeneration of collagen and abnormal elastotic fibrinogenesis (2, 25, 28-30). Recently, Di Vito et al. (31) reported that stroma and interspersed spindle cells of elastofibroma dorsi were positive for periostin and tenascin-C. It is possible that these two matricellular proteins may be involved in the development of fibrosis. In that study, the presence of tryptase-positive mast cells was also identified throughout the lesion. However, the precise role of mast cells in elastofibroma dorsi is not yet clarified. 


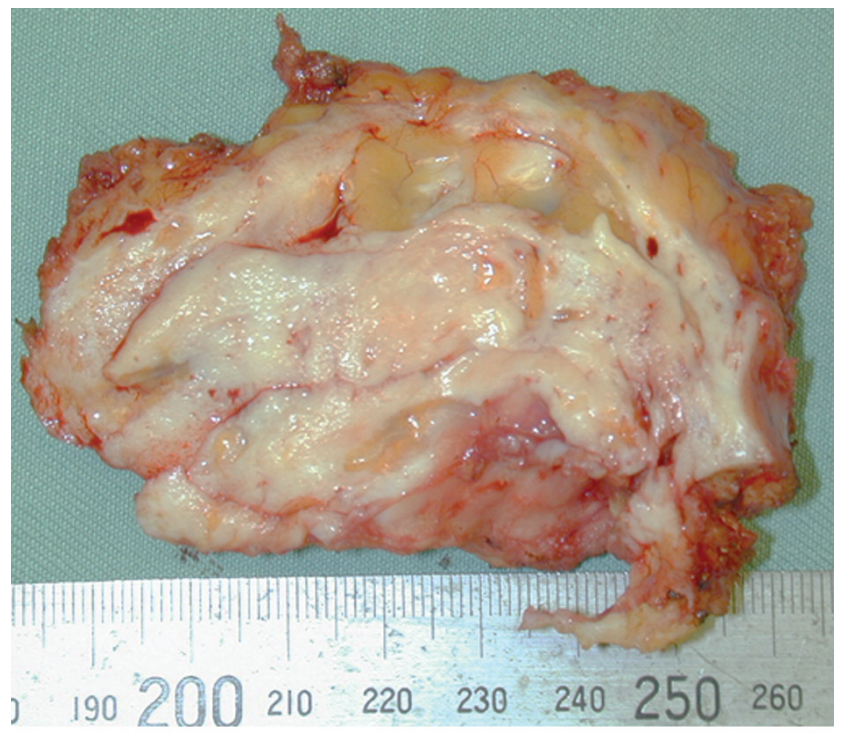

Figure 4. The cut surface of elastofibroma dorsi demonstrates a variegated appearance with an admixture of gray-white fibrous tissue and intervening yellow fat.

\section{Conclusion}

Elastofibroma dorsi is a distinctive benign fibroblastic pseudotumor and its associated prognosis is excellent with no recurrence. MRI is the mainstay of diagnosis for this lesion. We strongly recommend that a conservative wait and see strategy should be the front-line approach to newly diagnosed patients, irrespective of existing pain or other clinical symptoms. Recurrent abnormalities of $1 \mathrm{p}$ and $\mathrm{Xq}$ are prominent in elastofibroma dorsi. Further studies are required to determine the biological consequences of these genomic alterations in elastofibroma dorsi.

\section{Conflicts of Interest}

The Authors declare no conflicts of interest associated with this article.

\section{Authors' Contributions}

JN researched the literature and drafted the article. SN revised the article. KN performed the histological evaluations and reviewed the article. TY reviewed the article. All Authors read and approved the final article.

\section{Acknowledgements}

This study was supported in part by the Ogata Foundation.

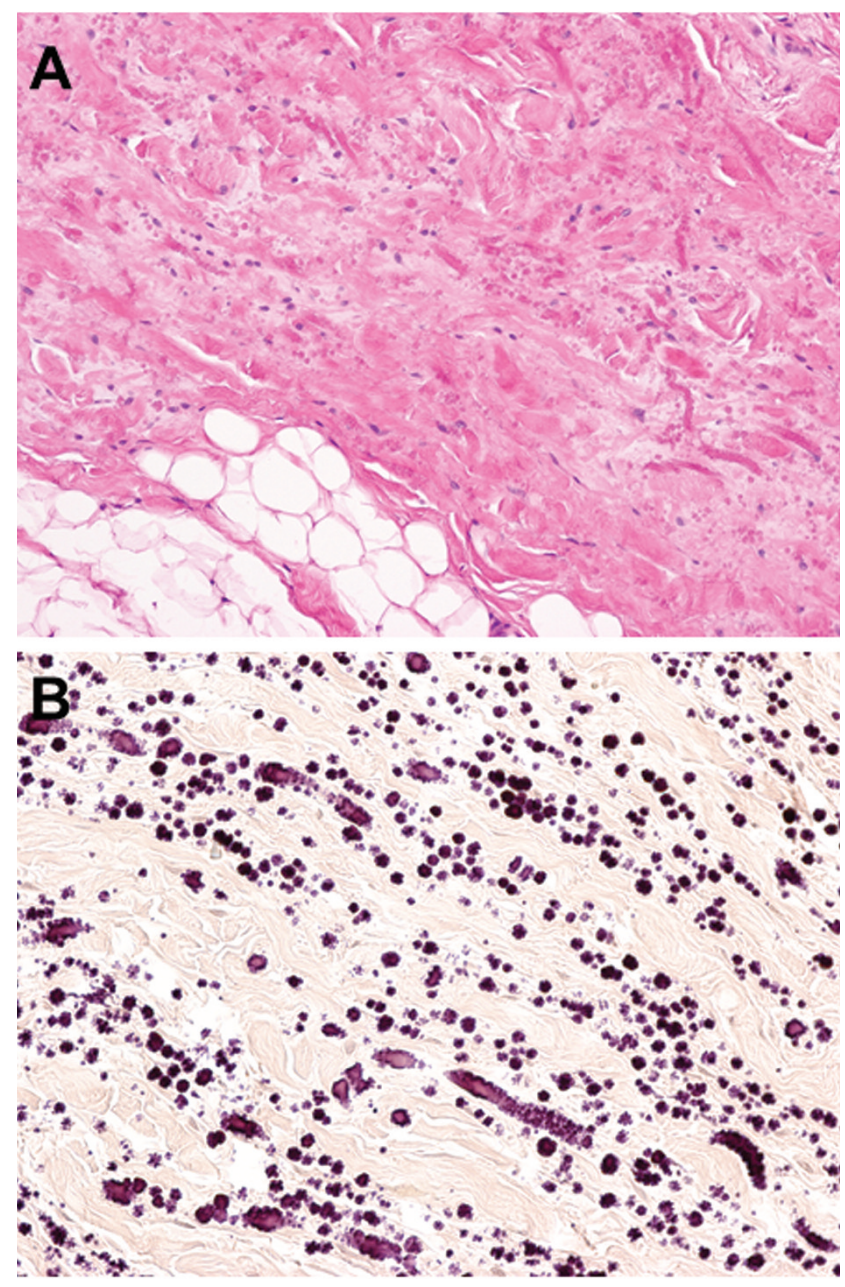

Figure 5. Histological findings of elastofibroma dorsi. (A) The lesion is composed of fibrocollagenous tissue containing eosinophilic elastic fibres and scattered fibroblasts with a variable amount of mature adipose tissue (hematoxylin and eosin stain, original magnification $\times 100)$. (B) Elastica van Gieson stain displays numerous globules and abnormal elastic fibres (original magnification $\times 200$ ).

\section{References}

1 Jarvi O and Saxen E: Elastofibroma dorse. Acta Pathol Microbiol Scand Suppl 51(Suppl 144): 83-84, 1961. PMID: 13789598.

2 Hisaoka $\mathrm{M}$ and Nishio J: Elastofibroma. In: World Health Organization classification of tumours of soft tissue and bone. Lyon, IARC Press, pp. 57-58, 2020.

3 Battaglia M, Vanel D, Pollastri P, Balladelli A, Alberghini M, Staals EL, Monti $\mathrm{C}$ and Galletti S: Imaging patterns in elastofibroma dorsi. Eur J Radiol 72(1): 16-21, 2009. PMID: 19539441. DOI: 10.1016/j.ejrad.2009.05.024

4 Nishio J, Isayama T, Iwasaki H and Naito M: Elastofibroma dorsi: diagnostic and therapeutic algorithm. J Shoulder Elbow Surg 21(1): 77-81, 2012. PMID: 21524925. DOI: 10.1016/j.jse.2011.01.043 
5 Bartocci M, Dell'Atti C, Meacci E, Congedo MT, Magarelli N Bonomo L and Leone A: Clinical features, imaging findings, treatment aspects of elastofibroma dorsi and long-term outcomes after surgical resection. Eur Rev Med Pharmacol Sci 21(9): 2061-2068, 2017. PMID: 28537680.

6 Tsubakimoto M, Yamashiro T, Tsuchiya N, Okada M, Maehara H, Kitsukawa $\mathrm{K}$ and Murayama S: MRI findings and demographics of elastofibroma dorsi: assessment of diffusion-weighted imaging and contrast enhancement patterns. Acta Radiol 59(6): 709-715, 2018. PMID: 28920444. DOI: 10.1177/0284185117732099

7 Onishi Y, Kitajima K, Senda M, Sakamoto S, Suzuki K, Maeda T, Yoshikawa T, Ohno Y and Sugimura K: FDG-PET/CT imaging of elastofibroma dorsi. Skeletal Radiol 40(7): 849-853, 2011. PMID: 20978756. DOI: 10.1007/s00256-010-1057-3

8 Fang N, Wang YL, Zeng L, Wu ZJ, Cui XJ, Wang Q, Gao S and Ding W: Characteristics of elastofibroma dorsi on PET/CT imaging with (18)F-FDG. Clin Imaging 40(1): 110-113, 2016. PMID: 26432711. DOI: 10.1016/j.clinimag.2015.08.009

9 Erhamamci S, Reyhan M, Nursal GN, Torun N, Yapar AF, Findikcioglu A and Canpolat T: Elastofibroma dorsi incidentally detected by (18)F-FDG PET/CT imaging. Ann Nucl Med 29(5): 420425, 2015. PMID: 25666569. DOI: 10.1007/s12149-015-0959-5

10 Hisaoka $\mathrm{M}$ and Hashimoto $\mathrm{H}$ : Elastofibroma: clonal fibrous proliferation with predominant CD34-positive cells. Virchows Arch 448(2): 195-199, 2006. PMID: 16133360. DOI: 10.1007/s00428005-0053-9

11 Vanni R, Marras S, Faa G, Uccheddu A, Dal Cin P, Sciot R, Samson I and Van den Berghe H: Chromosome instability in elastofibroma. Cancer Genet Cytogenet 111(2): 182-183, 1999. PMID: 10347562. DOI: 10.1016/s0165-4608(98)00243-x

12 McComb EN, Feely MG, Neff JR, Johansson SL, Nelson M and Bridge JA: Cytogenetic instability, predominantly involving chromosome 1, is characteristic of elastofibroma. Cancer Genet Cytogenet 126(1): 68-72, 2001. PMID: 11343783. DOI: 10.1016/s0165-4608(00)00395-2

13 Batstone P, Forsyth L and Goodlad J: Clonal chromosome aberrations secondary to chromosome instability in an elastofibroma. Cancer Genet Cytogenet 128(1): 46-47, 2001. PMID: 11458949. DOI: 10.1016/s0165-4608(01)00394-6

14 Nishio JN, Iwasaki H, Ohjimi Y, Ishiguro M, Koga T, Isayama T, Naito M and Kikuchi M: Gain of Xq detected by comparative genomic hybridization in elastofibroma. Int J Mol Med 10(3): 277-280, 2002. PMID: 12165800 .

15 Hernández JL, Rodríguez-Parets JO, Valero JM, Muñoz MA, Benito MR, Hernandez JM and Bullón A: High-resolution genome-wide analysis of chromosomal alterations in elastofibroma. Virchows Arch 456(6): 681-687, 2010. PMID: 20422214. DOI: 10.1007/s00428-010-0911-y

16 Nishio J, Ideta S, Aoki M, Hamasaki M, Nabeshima K, Iwasaki $\mathrm{H}$ and Naito M: Fibrolipoma of the ring finger: MR imaging and histological correlation. In Vivo 27(4): 541-544, 2013. PMID: 23812228

17 Nishio J, Aoki M, Nabeshima K, Iwasaki $H$ and Naito M: Imaging features of desmoid-type fibromatosis in the teres major muscle. In Vivo 27(4): 555-559, 2013. PMID: 23812231.

18 Nagano S, Yokouchi M, Setoyama T, Sasaki H, Shimada H, Kawamura I, Ishidou Y, Setoguchi $\mathrm{T}$ and Komiya $\mathrm{S}$ : Elastofibroma dorsi: Surgical indications and complications of a rare soft tissue tumor. Mol Clin Oncol 2(3): 421-424, 2014. PMID: 24772311. DOI: 10.3892/mco.2014.257
19 Chandrasekar CR, Grimer RJ, Carter SR, Tillman RM, Abudu A, Davies AM and Sumathi VP: Elastofibroma dorsi: an uncommon benign pseudotumour. Sarcoma 2008: 756565, 2008. PMID: 18382611 . DOI: $10.1155 / 2008 / 756565$

20 Scamporlino A, Ruggiero C, Aramini B, Morandi U and Stefani A: Surgery for elastofibroma dorsi: optimizing the management of a benign tumor-an analysis of 70 cases. J Thorac Dis 12(5): 1884-1894, 2020. PMID: 32642092. DOI: 10.21037/jtd-20-649

21 Nagamine N, Nohara Y and Ito E: Elastofibroma in Okinawa. A clinicopathologic study of 170 cases. Cancer 50(9): 1794-1805, 1982. PMID: 7116305. DOI: 10.1002/1097-0142(19821101) 50:9<1794::aid-cncr2820500925>3.0.co;2-1

22 Schepel JA, Wille J, Seldenrijk CA and van Ramshorst B: Elastofibroma: a familial occurrence. Eur J Surg 164(7): 557558, 1998. PMID: 9696981. DOI: 10.1080/1102415 98750005967

23 Akçam Tİ, Çağırıcı U, Çakan A and Akın H: Bilateral familial elastofibroma dorsi: is genetic abnormality essential? Ann Thorac Surg 98(2): e31-e32, 2014. PMID: 25087826. DOI: 10.1016/j.athoracsur.2014.04.138

24 Olchowy C, de Delás-Vigo MA, Perez M, Ciriaco N and Oronoz RD: Triple elastofibromas located in the supra- and infrascapular regions-a case report. Skeletal Radiol 47(4): 569-573, 2018. PMID: 29170811. DOI: 10.1007/s00256-017-2813-4

25 Järvi OH, Saxén AE, Hopsu-Havu VK, Wartiovaara JJ and Vaissalo VT: Elastofibroma - a degenerative pseudotumor. Cancer 23(1): 42-63, 1969. PMID: 4303173. DOI: 10.1002/10970142(196901)23:1<42::aid-cncr2820230105>3.0.co;2-\#

26 Giebel GD, Bierhoff E and Vogel J: Elastofibroma and preelastofibroma - a biopsy and autopsy study. Eur J Surg Oncol 22(1): 93-96, 1996. PMID: 8846878. DOI: $10.1016 / \mathrm{s} 0748-$ 7983(96)91781-3

27 Findikcioglu A, Kilic D, Karadayi Ş, Canpolat T, Reyhan M and Hatipoglu A: A thoracic surgeon's perspective on the elastofibroma dorsi: A benign tumor of the deep infrascapular region. Thorac Cancer 4(1): 35-40, 2013. PMID: 28920318. DOI: $10.1111 / \mathrm{j} .1759-7714.2012 .00139 . \mathrm{x}$

28 Stemmermann GN and Stout AP: Elastofibroma dorsi. Am J Clin Pathol 37: 499-506, 1962. PMID: 13916810. DOI: 10.1093/ ajcp/37.5.499

29 Fukuda Y, Miyake H, Masuda Y and Masugi Y: Histogenesis of unique elastinophilic fibers of elastofibroma: ultrastructural and immunohistochemical studies. Hum Pathol 18(5): 424-429, 1987. PMID: 3552953. DOI: 10.1016/s0046-8177(87)80026-6

30 Kumaratilake JS, Krishnan R, Lomax-Smith J and Cleary EG: Elastofibroma: disturbed elastic fibrillogenesis by periostealderived cells? An immunoelectron microscopic and in situ hybridization study. Hum Pathol 22(10): 1017-1029, 1991. PMID: 1842374. DOI: 10.1016/0046-8177(91)90010-m

31 Di Vito A, Scali E, Ferraro G, Mignogna C, Presta I, Camastra C, Donato G and Barni T: Elastofibroma dorsi: a histochemical and immunohistochemical study. Eur J Histochem 59(1): 2459, 2015. PMID: 25820560. DOI: 10.4081/ejh.2015.2459

Received March 29, 2021

Revised April 13, 2021

Accepted April 14, 2021 